Global Conferences Series:

Sciences and Technology (GCSST), Volume, 5, 2020

Seminar Nasional I Baristand Industri Padang (Semnas I BIPD)

DOI: https://doi.org/10.32698/GCS-SNIIBIPD3430

\title{
Phenology of rice-fields and dryland using enhanced vegetation index (EVI) analysis the evaluation of planting season
}

\section{Fenologi lahan pertanian sawah dan lahan kering menggunakan analisis enhanced vegetation indeks (EVI) dalam evaluasi musim tanam}

\author{
Febby Monia ${ }^{1}$, Kharistya Amaru ${ }^{1}$, Shopia Dwiratna N.P' ${ }^{1}$, Dwi Rustam K ${ }^{1}$ \\ ${ }^{1}$ Undergraduate Program, Faculty of Agricultural Industry Technology, Universitas Padjajaran, Bandung, \\ Indonesia
}

\begin{abstract}
Citarik Sub-watershed, Cikeruh-Citarik River Basin is upstream zone of Citarum-watershed which plays a role in agricultural sector at Bandung-Sumedang Regency. Limited water during the dryseason makes planting season limited 1-2 times a year. Information is needed regarding condition area with limited planting season through phenological detection using satellite image processing. Study aims provide information related to distribution ricefields and dryland, when planting season is effective. Study uses EVI analysis method from Landsat 8 image data on Google Earth Engine platform which consists of image preprocessing, analysis stage, visual interpretation 5-3-2 NIR-Green-Blue Band combination image, supervised-unsupervised classification, detecting phenology, field inspection, and accuracy test. Results analysis form land cover maps for 2019 from January to December are dominated ricefields covering an area of 50,073 hectare and dry land 42,865 hectare. Graph EVI value ricefields shows highest value 0.77 and lowest 0.21. Estimated productivity first rice planting season is December-February, second month May-June and following months do not occur due to water shortages during dry season. Accuracy agricultural land classification is indicated by overall accuracy kappa $96 \%$ and meets USGS requirements (>90\%). It shows that EVI analysis method of agricultural land phenology can be used to monitor planting season time in study area.
\end{abstract}

Keywords: phenology analysis; EVI; GEE

\begin{abstract}
Abstrak: Sub-DAS Citarik, DTA Sungai Cikeruh-Citarik merupakan zona hulu DAS Citarum yang berperan dalam sektor pertanian wilayah Kabupaten Bandung-Sumedang. Keterbatasan air pada musim kemarau membuat musim tanam menjadi terbatas 1-2 kali dalam setahun sehingga diperlukan informasi mengenai kondisi luasan wilayah dengan musim tanam terbatas melalui deteksi fenologi menggunakan pengolahan citra satelit. Penelitian bertujuan memberikan informasi terkait sebaran luasan sawah dan lahan kering, waktu musim tanam efektif. Penelitian menggunakan metoda analisis EVI dari data citra landsat 8 pada platform Google Earth Engine terdiri dari pra-pengolahan citra, tahap analisis, interpretasi visual citra kombinasi band 5-3-2 NIR-Green-Blue, pengklasifikasian supervised-unsupervised, mendeteksi fenologi, groundcheck lapangan, dan uji akurasi. Hasil analisa berupa peta tutupan lahan tahun 2019 bulan JanuariDesember didominasi oleh sawah seluas 50.073 ha dan lahan kering 42.865 Ha. Grafik nilai EVI pada sawah menampilkan nilai tertinggi 0,77 dan terendah 0,21 . Estimasi produktivitas fase musim tanam sawah pertama bulan Desember-Februari, kedua bulan Mei-Juni dan bulan selanjutnya tidak terjadi penanaman karena keterbatasan air di musim kemarau. Ketelitian klasifikasi lahan pertanian ditunjukkan dengan akurasi overall dan kappa masing-masing sebesar $96 \%$ dan memenuhi syarat yang ditetapkan USGS $(>90 \%)$. Hal tersebut menunjukkan bahwa metoda analisis EVI untuk fenologi lahan pertanian dapat digunakan untuk monitoring waktu musim tanam di daerah penelitian.
\end{abstract}

Kata kunci: analisis fenologi; EVI; GEE

Copyright (C) 2020, the Authors. Published by Redwhite Press.

This is an open access article under the CC BY-NC license

(http://creativecommons.org/licenses/by-nc/4.0). 


\section{PENDAHULUAN}

Wilayah Sub DAS Citarik terletak pada koordinat 60o49' LS -70o49' LS dan 107o30’ BT - 107o57' BT merupakan zona hulu DAS Citarum yang mempunyai tiga daerah pengaliran atau daerah tangkapan air yaitu DTA sungai Citarik, DTA Sungai Cipamokolan, DTA sungai Cikeruh. Dari hasil data survei lapangan bulan September 2019 wilayah ini memiliki peranan penting dalam sektor pertanian yang menjadi sumber utama penghasilan dan fungsi ekologi (lingkungan) di wilayah tersebut.

Penelitian ini dilakukan di wilayah DTA sungai cikeruh dan DTA sungai citarik, meliputi dua Kabupaten yaitu Kabupaten Bandung (Cileunyi, Rancaekek, Cibiru, Rancasari, Cicalengka, Cimanggung, Ciparay, Majalapya, Kertasari, Pacet) dan Kabupaten Sumedang (Tanjungsari, Jatinangor, Sukasari). Kondisi penggunaan lahan pada area ini terdiri dari lahan pemukiman, sawah irigasi, sawah tadah hujan, tegalan, semak, kebun, dan perkebunan.

Penggunaan lahan pertanian oleh masyarakat seringkali dilakukan tanpa adanya sebuah perencanaan yang matang, karena keterbatasan informasi tentang fenologi perencanaan penggunaan lahan pertanian. Fenologi mempelajari hubungan antara perkembangan tanaman dengan perubahan iklim dan musim, seperti suhu dan lamanya pencahayaan per hari, terutama terhadap perubahan dalam bentuk fenomena yang periodek seperti proses pembentukan daun, bunga dan dormansi. Metode deteksi fenologi dapat menentukan tanggal heading untuk mengestimasi produktivitas tanaman pada lahan pertanian sawah dan lahan kering.

Selain itu dari hasil survey langsung yang dilakukan di wilayah Sub DAS Citarik terdapat permasalahan yang terjadi pada penggunaan lahan pertanian dalam menentukan jadwal musim tanam yang cocok untuk bertanam. Masyarakat mengalami kesulitan dalam hal memantau perkembangan musim tanam pada pertanian secara cepat, akurat, dan berkelanjutan akibatnya musim tanam menjadi terbatas 1-2 kali dalam setahun hingga mengalami gagal tanam bibit (rusak) sebelum bertanam karna kondisi kering ketika musim kemarau.

Penelitian ini dilaksanakan sebagai salah satu cara untuk mengatasi masalah yang dialami para petani di wilayah DTA Sungai Cikeruh-Citarik dalam penentuan musim tanam lahan sawah dan permasalahan lahan kering di musim kemarau sehingga data yang dihasilkan dapat menjadi data penunjang pengaliran air irigasi yang merata dan optimal.

Oleh karena itu dibutuhkan suatu analisis yang dapat memberikan informasi spasial untuk keperluan pemantauan lahan pertanian, seperti pemantauan luasnya lahan tanam sawah, lahan kering dan produktivitas kalender tanam lahan setiap area serta bagaimana perencanaan penggunaan lahan dalam pertanian untuk masa yang akan datang melalui deteksi fenologi menggunakan pengolahan citra satelit.

Hasil dari proses analisis akan menghasilkan keluaran (output) deteksi fenologi lahan pertanian berupa grafik profil waktu EVI pada piksel lahan pertanian, distribusi spasial berupa peta dan data estimasi citra landsat berupa tabel. Hasil analisis tersebut kemudian digunakan untuk memetakan kalender tanam serta mengestimasi luas tanam.

\section{METODE}

Wilayah Sub DAS Citarik DTA Sungai Cikeruh dan Citarik, Kabupaten Bandung dan Sumedang terletak pada koordinat 60o49’ LS -70o49' LS dan 107o30’ BT - 107o57’ BT. Meliputi dua Kabupaten yaitu Kabupaten Bandung (Cileunyi, Rancaekek, Cibiru, Rancasari, Cicalengka, Cimanggung, Ciparay, Majalapya, Kertasari, Pacet) dan Kabupaten Sumedang (Tanjungsari, Jatinangor, Sukasari).

Analisis EVI pada platform Google Earth Engine yang dilaksanakan pada bulan Januari sampai dengan Desember 2019 menggunakan input koding JavaScript API (Application Programming Interface). Pengumpulan data dimulai pada data spasial tata guna lahan seperti batas wilayah, dan penggunaan lahan sebagai data groundcheck di wilayah sub DAS Citarik DTA Cikeruh dan Citarik tahun 2018. Menggunakan metode terbimbing (Supervised) dan tidak terbimbing (Unsupervised). 


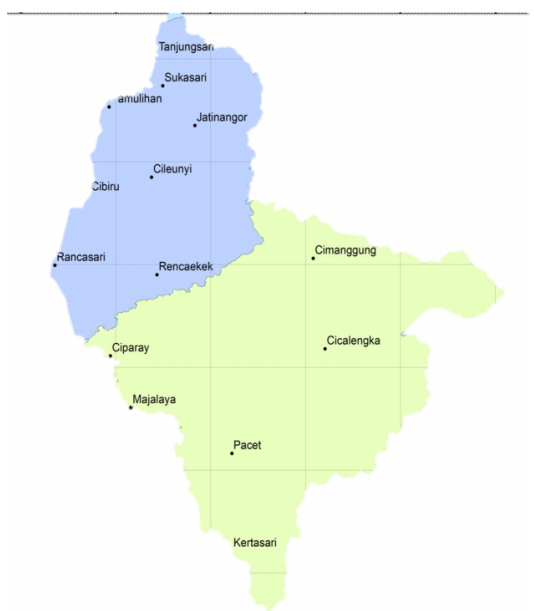

Gambar 1. Peta Sub DAS Citarik DTA Sungai Cikeruh dan Citarik

\section{Tahap Pengumpulan Data Menggunakan Metode Supervised (Terbimbing)}

Supervised pra-pengolahan citra, untuk menetapkan beberapa daerah pada citra sebagai kelas lahan. Penetapan ini berdasarkan pengetahuan analis terhadap wilayah dalam citra mengenai daerah-daerah penelitian. nilai-nilai pixel dalam daerah tersebut kemudian digunakan oleh GEE sebagai kunci untuk mengenai pixel yang lain. Metode ini digunakan untuk mengidentifikasi kelas informasi mengenai lahan terlebih dulu dan kemudian akan digunakan untuk menentukan kelas spectral yang mewakili kelas informasi tersebut.

\section{Tahap Pengolahan Data Supervised (Terbimbing)}

Tahap pertama melakukan pengolahan data pada penelitian ini yaitu melakukan input data asset shape file batas wilayah, penggunaan lahan, dan sub DAS. Penginputan data shape file DAS ini bertujuan untuk memperoleh batas sub DAS, penggunaan lahan, dan jaringan sungai pada layer GEE. Penginputan data shape file DAS dilakukan secara otomatis pada input assets yang terdapat pada GEE. Data shape file digunakan sebagai data masukan untuk melakukan analisis EVI dan Fenologi secara temporal pada citra landsat di Google Earth Engine.

Tahap kedua karena Google Earth Engine sebuat platform berbasis cloud, memerlukan input skrip earth engine menggunakan bahasa pemograman koding javascript untuk menjalankan perintah program. Input javascript dapat membantu proses membuat prototype serta visualisasi data spasial yang kompleks menggunakan javascript API lebih cepat dalam menampilkan output hasil di platform.

Tahap berikutnya setelah input data shape file penggunaan lahan yaitu menginput koding analisis EVI pada Script, dan melakukan perhitungan observasi wilayah untuk menghasilkan nilai EVI. Algoritma yang digunakan untuk menghitung EVI adalah (Huete et al., 2007):

dimana:

$E V I=2,5 \times \frac{\rho \mathrm{NIR}-\rho \mathrm{pred}}{\rho \mathrm{NIR}+\text { pred }-7,5 \times \text { pblue }+1}$.

$\rho N I R$ adalah reflektansi inframerah-dekat, $\rho$ red adalah reflektansi merah, $\rho$ blue adalah reflektansi biru.

Script yang digunakan dalam input analisis EVI sebagai berikut:

var analisis $=$ ee.ImageCollection $\left(' L A N D S A T / L C 08 / C 01 / T 1 \_32 D A Y \_E V I '\right)$

var evi = ee.Image(analisis

filterDate('2019-01-01','2019-12-31')

filterBounds(geometry)

.map(function(image)\{return image.clip(geometry)\})

.sort('CLOUDCOVER')

first()); $\operatorname{print}($ evi)

$\operatorname{var} C C=\{\min : 0, \max : 1.0$,

palette: ["blue","maroon", "green","yellow","orange", "white"]\};

Map.setCenter(107.7861, -6.9506); Map.addLayer(evi,CC,'Landsat') 


\section{Tahap Analisis Supervised (Terbimbing)}

Penggunaan metode Binary Encoding sebagai klasifikasi pengkodean biner data spektrum endmember ke nol dan satu berdasarkan sebuah band diatas spektrum data yang menghasilkan gambar klasifikasi untuk analisis (Hairil, 2011). Semua piksel diklasifikasikan ke endmember dengan jumlah terbesar dari band yang cocok, dan menentukan minimum match threshold untuk memenuhi kriteria dalam klasifikasi (Sakamoto et al., 2015).

Pemilihan kombinasi band terbaik untuk klasifikasi tutupan lahan melalui evaluasi Optimum Index Factor (OIF) banyaknya komposit yang terdapat pada rentang nilai spektral landsat 8 ditunjukkan pada tabel 1 ,

Analisis interpretasi visual citra untuk pengenalan karakteristik obyek secara spasial berdasarkan unsur-unsur interpretasi seperti warna, bentuk, ukuran, pola, bayangan yang diinterpretasi ditampilkan dalam format RGB (Red Green Blue) dalam bentuk citra komposit, membuat klasifikasi kelas dari suatu training area, feature space, atau cluster yang mewakili satu kelas tutupan lahan (Lili, 2010), misalnya hutan, sawah, pemukiman, perairan, dan sebagainya. analisis separabilitas untuk mengevaluasi keterpisahan area contoh (training area) dari setiap kelas apakah layak digabung atau tidak untuk klasifikasi band terbaik. Klasifikasi band menggunakan script berikut:

var band $=\{$ min:0, max:0.2, bands: ['B4', 'B3', 'B2']\};

Map.addLayer(\{bands: ['B4', 'B3', 'B2'], min: 0, max: 3000\});

Tabel 1. Kanal pada Satelit Landsat 8

\begin{tabular}{llll}
\hline Landsat 8 & Band & $\begin{array}{l}\text { Panjang Gelombang } \\
\text { (mikrometer) }\end{array}$ & $\begin{array}{l}\text { Resolusi } \\
\text { (meter) }\end{array}$ \\
\hline & Band 1 - Coastal aerosol & $0,43-0,45$ & 30 \\
Operational & Band 2 - Blue & $0,45-0,51$ & 30 \\
Land Imager (OLI) & Band 3 - Green & $0,53-0,59$ & 30 \\
& Band 4 - Red & $0,64-0,67$ & 30 \\
dan & Band 5 - Near Infrared (NIR) & $0,85-0,88$ & 30 \\
& Band 6 - SWIR 1 & $1,57-1,65$ & 30 \\
Thermal Infrared & Band 7 - SWIR 2 & $2,11-2,29$ & 30 \\
Sensor (TIRS) & Band 8 - Panchromatic & $0,50-0,68$ & 15 \\
& Band 9 - Cirrus & $1,36-1,38$ & 30 \\
& Band 10 - Thermal Infrared (TIRS) 1 & $10,60-11,19$ & 100 \\
\hline
\end{tabular}

Sumber : Son et al., 2014

Tahap Pengecekan Hasil Analisis Menggunakan Metode Unsupervised (Tidak Terbimbing)

Sistem kerja unsupervised dengan melakukan pengelompokan nilai-nilai pixel suatu citra kedalam kelas-kelas spektral dengan menggunakan algoritma klusterisasi (Justice, 2014). Metode unsupervised yang digunakan menggunakan metode IsoData untuk mengklasifikasikan kelas secara merata dari setiap pixel diklasifikasikan ke kelas terdekat. Diawali proses biasanya analis (orang yang melakukan analisis) akan menentukan jumlah kelas (cluster) yang akan dibuat (Jaya, 2015). Kemudian setelah mendapatkan hasil, analis menetapkan kelas-kelas lahan menjadi kelas-kelas spektral yang telah dikelompokan dari hasil kombinasi band interpretasi citra pada GEE (Martinez, 2010). Dari hasil klasifikasi kelas yang dihasilkan, analis bisa menggabungkan beberapa kelas yang dianggap memiliki informasi yang sama menjadi satu kelas. Misal kelas 1, 2, dan 3 masing-masing adalah sawah, pemukiman, lahan kering, badan air dan hutan maka bisa dikelompokkan setiap kelasnya.

Pengelompokkan kelas yang diutamakan dalam klasifikasi pada MS.Excell adalah klasifikasi kelas lahan sawah dan lahan kering yang akan digunakan sebagai data masukan dalam hasil analisis ini untuk mengetahui jadwal musim tanam di lahan sawah dan titik point tutupan lahan kering sebagai data masukan dalam mengatasi permasalahan penggunaan lahan di wilayah sub DAS Citarik DTA sungai Cikeruh dan Citarik.

Hasil dari penentuan cluster atau klasifikasi menjadi patokan untuk melakukan groundcheck lapangan sebagai pencatatan data mengenai penarikan sampel yang dapat mewakili karakteristik dari suatu wilayah dengan cara melakukan crosscheck data training area dan data hasil karakteristik klasifikasi dengan dibandingkan menggunakan data hasil uji akurasi kappa. Hasil data lapangan yang telah dibandingkan dengan uji akurasi kappa dapat dikatakan akurat jika hasil $>90 \%$.

Klasifikasi unsupervised menggunakan data groundcheck penggunaan lahan di wilayah DTA sungai Cikeruh dan Citarik sebagai acuan klasifikasi supervised (terbimbing) yang digunakan untuk analisis kelas tutupan lahan di wilayah training area yang dianalisis EVI dan kompositnya. 


\section{Uji Akurasi Hasil Analisis EVI}

Uji akurasi hasil deteksi fenologi dilakukan menggunakan Bahasa pemograman JavaScript di layer Script GEE. Hasil deteksi akan menunjukkan nilai kappa matrix error yang telah dihasilkan pada tahap analisis EVI hanya dengan menginput koding perhitungan kappa di program GEE. Perhitungan kappa berfungsi untuk uji akurasi. Uji akurasi digunakan untuk mengetahui tingkat kesalahan (matrix error) yang terjadi pada klasifikasi training area sehingga dapat ditentukan besarnya persentase ketelitian pemetaan. Akurasi ketelitian pemetaan dilakukan dengan membuat matrik kontingensi atau matrik kesalahan (confusion matrix) seperti berikut (Jaya, 2010):

Kappa (k) $\quad=\frac{\mathrm{N} \Sigma_{i}^{\mathrm{r}} \mathrm{Xi}-\Sigma_{\mathrm{i}}^{\mathrm{r}} \mathrm{Xi}+\mathrm{X}+\mathrm{i}}{\mathrm{N}^{2}-\Sigma_{\mathrm{i}}^{\mathrm{r}} \mathrm{Xi}+\mathrm{X}+\mathrm{i}} \times 100 \%$

$\mathrm{N}$ adalah banyaknya piksel dalam contoh, $\mathrm{X}$ adalah nilai diagonal dari matriks kontingen baris ke-i dan kolom ke-i, Xii adalah jumlah piksel dalam baris ke-i, Xi+ adalah jumlah piksel dalam kolom ke-i.

Analisis untuk uji akurasi dan nilai kappa pada hasil analisis klasifikasi kelas tutupan lahan EVI dapat menginput script berikut :

var confMatrix = classifier.confusionMatrix();

var $O A=$ confMatrix.accuracy();

var Kappa = confMatrix.kappa();

print('OA: ', OA) print('Kappa: ', Kappa);

Hasil perhitungan kappa akan menghasilkan keakuratan nilai untuk hasil analisis fenologi secara temporal yang terdapat di wilayah tersebut. (2010):

Algorithma dan threshold untuk mendeteksi tahap-tahap fenologi tanaman yang dijabarkan oleh Sari

a. Tanggal Heading (HD) Identifikasi tahap-tahap fenologi lahan pertanian diawali dengan mendeteksi untuk tanggal heading (HD). Pada metode deteksi fenologi ini tanggal ketika EVI mencapai nilai maksimum dalam grafik profil waktu didefinisikan sebagai estimasi tanggal heading dengan EVI $\geq$ 0,5 sebagai threshold (Sari, 2010). Profil waktu EVI satu tahun dibagi menjadi 12 periode untuk mencari nilai maksimum EVI pada masing-masing caturwulan (1 bulan untuk setiap periode) (Sari et al., 2010).

Penentuan tanggal heading dapat menggunakan script berikut :

var evi = ee.Image(analisis

filterDate('2019-01-01','2019-12-31') //Tanggal diatur sesuai kebutuhan

filterBounds(geometry)

.map(function(image)\{return image.clip(geometry)\})

.sort('CLOUDCOVER')

$\operatorname{print}(e v i)$

first()),

\section{HASIL DAN PEMBAHASAN}

Interpretasi Citra

Interpretasi Citra berdasarkan data landsat 8 yang digunakan untuk analisis klasifikasi tutupan lahan menggunakan kombinasi dari band terbaik analisis EVI menggunakan kombinasi band 4 (Red), 3(Green), 2(Blue).

Hasil dari kombinasi band RGB membantu pengamatan dalam mengetahui objek-objek tutupan lahan secara visual yang terdapat di lapangan di wilayah Sub DAS Cikeruh dan Citarik DTA Sungai Cikeruh dan Citarik teridentifikasi menjadi 5 kelas tutupan lahan terdiri dari biru (badan air), green (hutan), maroon (bangunan), yellow-orange (sawah), dan nude-white (lahan kering). Kenampakan jenis tutupan lahan pada citra ditampilkan dengan warna yang berbeda. Hutan dengan kerapatan vegetasi tinggi akan tampak dengan warna hijau gelap (dark green). Berikut kenampakan reflektan objek dari setiap pixel objek permukaan bumi dengan kombinasi band RGB (432). 


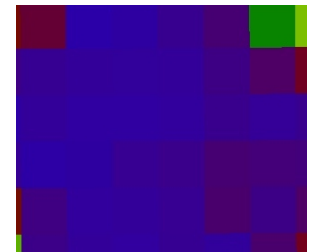

(a) Badan air

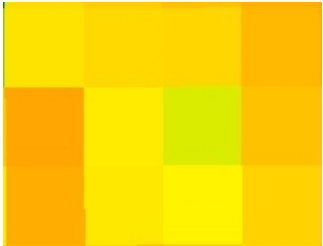

(b) Sawah

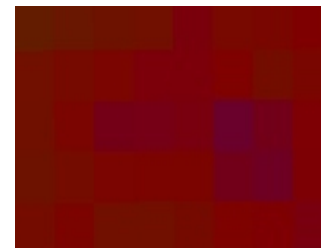

(c) Bangunan

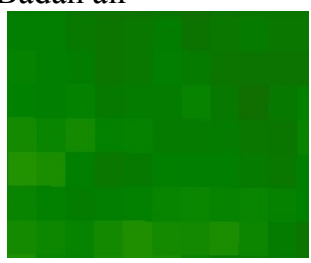

(d) Hutan

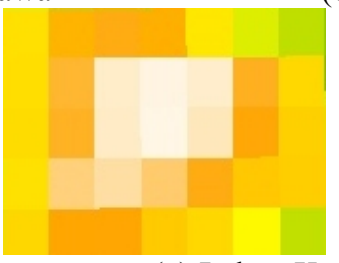

(e) Lahan Kering

Gambar 2. Pixel Klasifikasi RGB

Klasifikasi Tutupan Lahan Data di Sub DAS Cikeruh dan Citarik DTA Sungai Cikeruh dan Citarik

Hasil klasifikasi tutupan lahan data Citra Landsat 8 menggunakan Algorithma EVI ditunjukkan pada Gambar 3. Data gambar Peta yang dihasilkan terdiri data set tahun 2019.

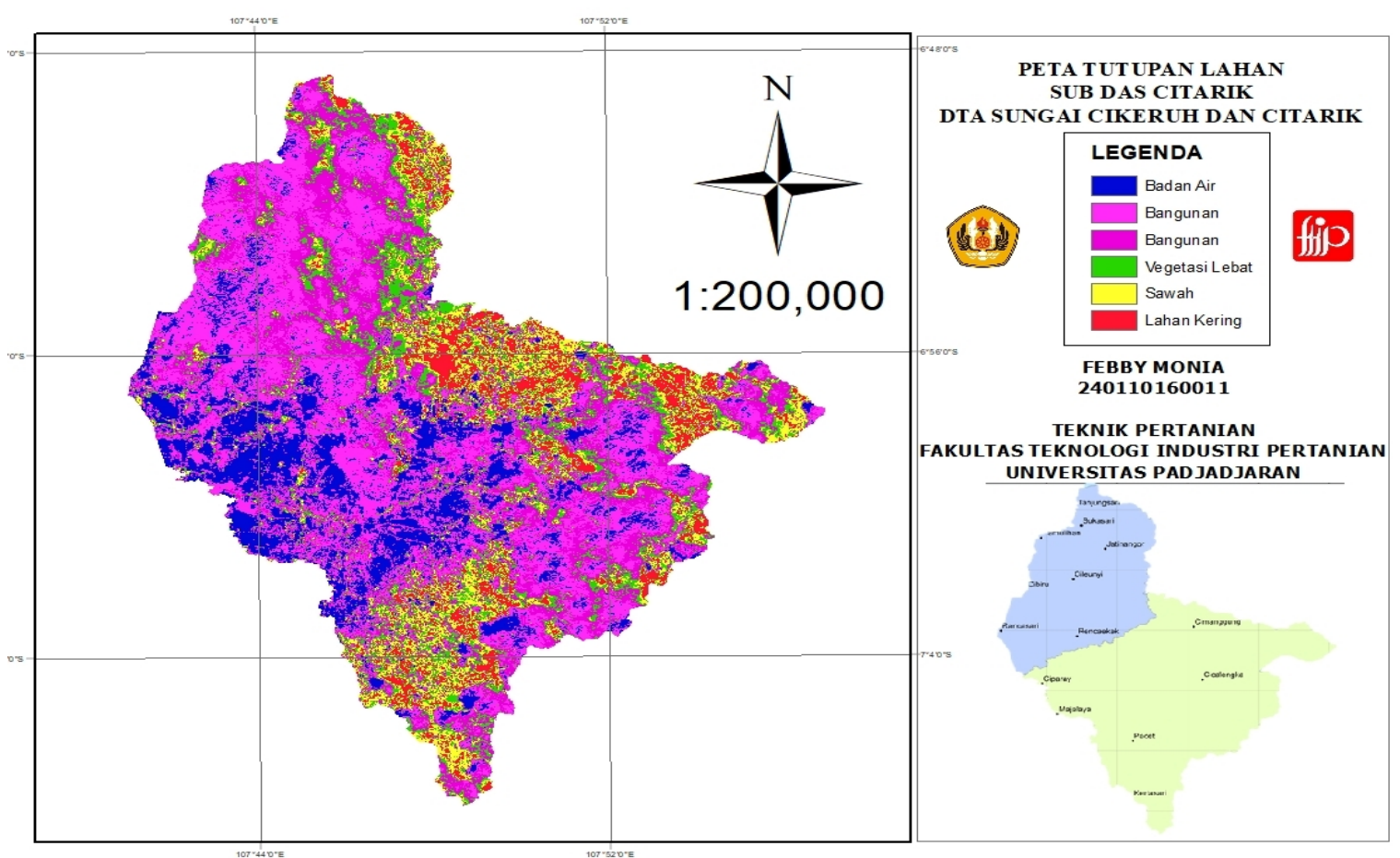

Gambar 3. Peta Tutupan Lahan EVI Sub DAS Citarik DTA Sungai Cikeruh dan Citarik Tahun 2019

Secara visual, setiap kelas dapat diidentifikasi menggunakan pengklasifikasi berdasarkan pengetahuan analis. Bagian utara tersebar vegetasi lebat (hutan), sawah, dan lahan kering. Sawah dan lahan kering terbanyak terdapat pada bagian Timur dan Selatan. Bagian barat sebagian besar merupakan lahan terbangun yang merupakan wilayah perkembangan dari Kota dan Kabupaten Bandung. Bagian barat daya wilayah Kabupaten Bandung terdapat penggunaan lahan situ (badan air) aliran sungai Cikeruh Citarik yang bermuara ke sungai citarum.

\section{Grafik EVI Lahan Sawah}

Hasil pada Gambar 4 menunjukkan terjadinya pertumbuhan yang tidak stabil pada setiap daerahya. Wilayah Kabupaten Sumedang terdapat pertumbuhan yang tidak stabil pada wilayah Sukasari, Pamulihan, Cileunyi, Cibiru, Rancasari dan Rancaekek. Banyak daerah yang memiliki pertumbuhan kurang optimal, yang dikarenakan masih kurangnya pengolahan dalam penggunaan lahan di pertanian terutama sawah. 
Kecamatan Pamulihan, Sukasari, dan Rancaekek masih sangat kurang dalam pengolah wilayah lahan sawah, pengolahan lahan sawah yang kurang tepat sehingga mengakibatkan pertumbuhan yang kurang optimal pada lahan sawah. Menurut pemda alih fungsi pada lahan sawah belum optimal dan masih dalam pekembangan untuk menaikkan sejumlah inovasi produktivitas dalam meningkatkan produksi pada lahan sawah.

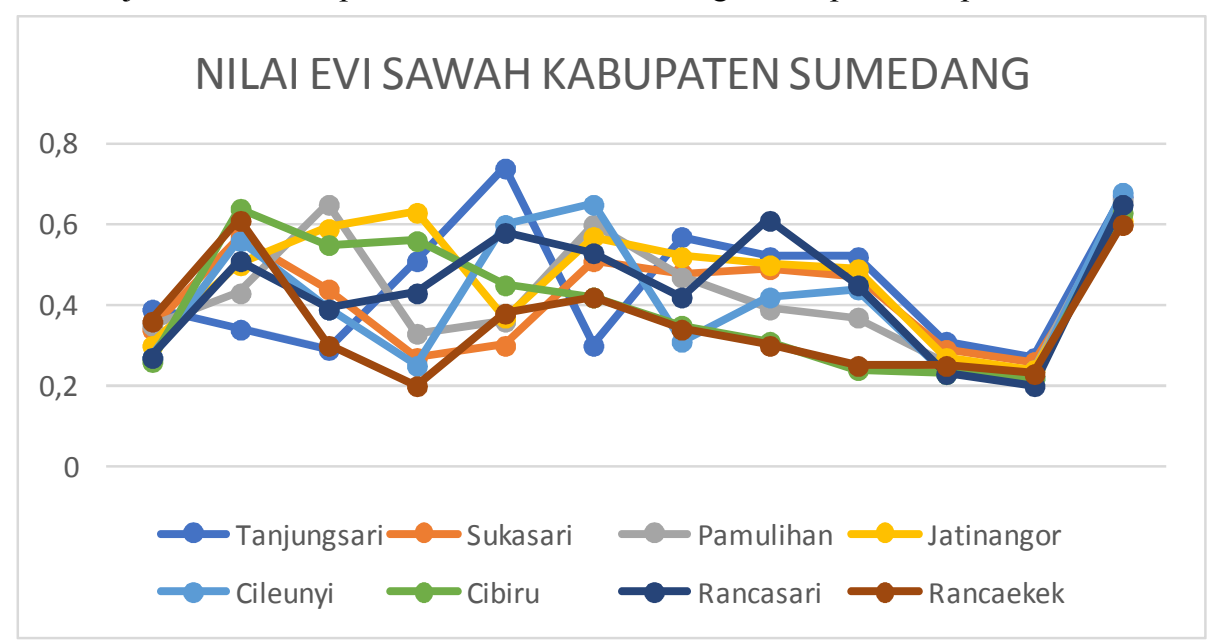

Gambar 4. Nilai EVI Kabupaten Sumedang

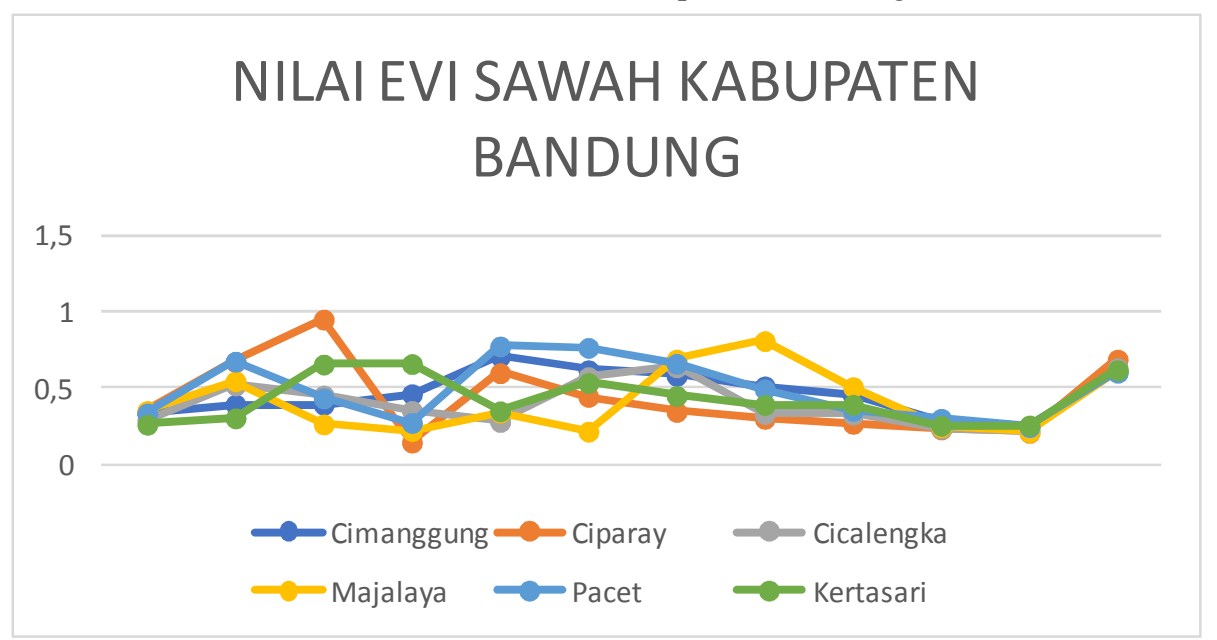

Gambar 5. Nilai EVI Kabupaten Bandung

Lahan sawah sangat memerlukan peng-irigasian sebagai penunjang untuk mengalirkan air pada saat persediaan air pada dalam tanah tidak mencukupi dalam mendukung kebutuhan pertumbuhan tanaman. Adanya irigasi secara merata dan teralirkan sesuai kebutuhan lahan pertanian dapat membantu pertumbuhan tanaman secara optimal.

Terdapat permasalahan pada wilayah kabupaten bandung meskipun wilayah disana terdapat situ atau aliran sungai masih terdapat permasalahan yang mengakibatkan pertumbuhan tanaman tidak stabil, menurut Purwowidodo (1983) peng-irigasian yang kurang dan tidak merata sehingga air yang dibutuhkan untuk pertumbuhan tanaman tidak dapat mengalir secara optimal yang mengakibatkan pertumbuhan tanaman terutama lahan sawah tidak stabil dan tidak optimal.

\section{Grafik Lahan Kering}

Hasil analisis menunjukkan terdapatnya lahan kering diwilayah Kabupaten Sumedang dan Kabupaten Bandung Sub DAS Citarik DTA Sungai Cikeruh dan Citarik yang dapat dilihat pada Gambar 6 grafik. Dari data yang ditunjukkan pada grafik lahan kering Kabupaten Sumedang menujukkan tingkat lahan kering diwilayah tersebut seluas 1973 hektar, dikarenakan wilayah yang masih kurang pengolahan dalam penggunaan lahan terutama pada pertanian. Banyak wilayah dikabupaten sumedang yang masih belum mendapatkan pengaliran irigasi yang merata dikarenakan wilayah yang tidak terjangkau dan jauh dari sumber aliran sungai, sehingga banyak lahan yang kering dan tidak dapat digunakan untuk bercocok tanam. 


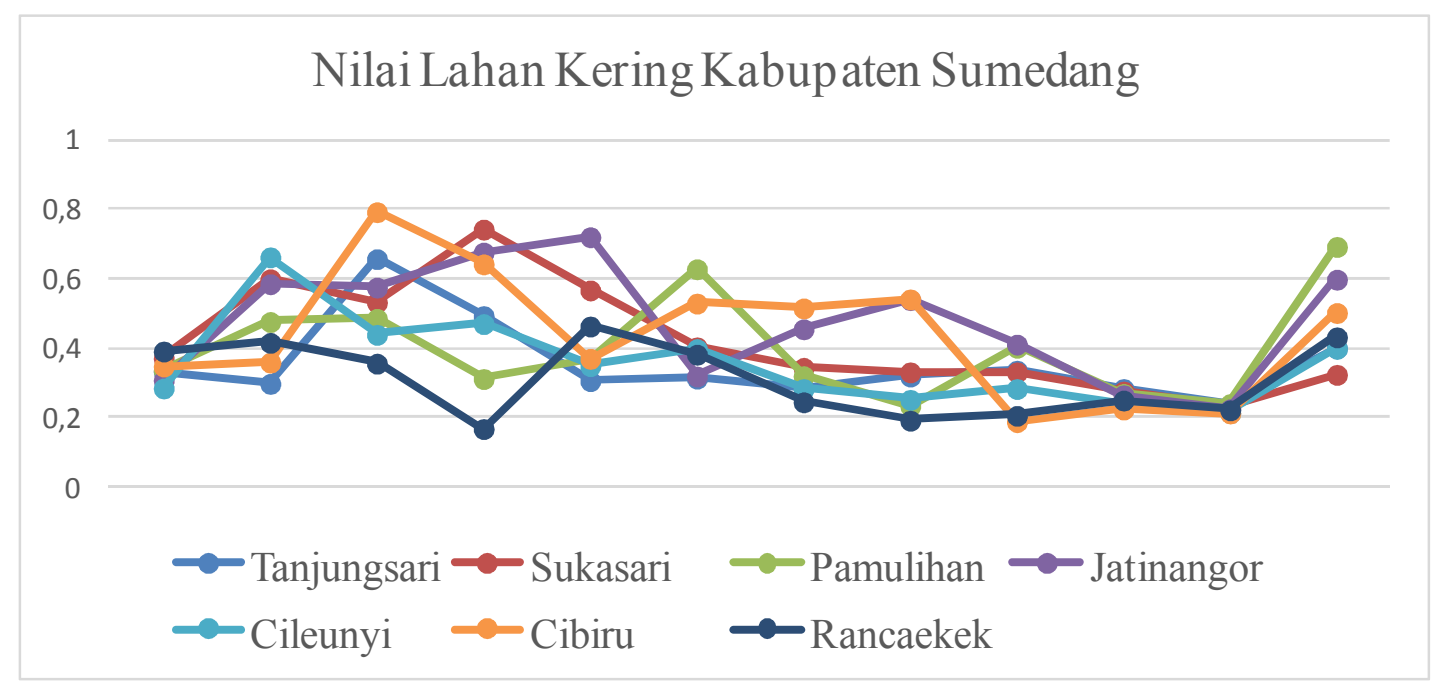

Gambar 6. Nilai Lahan Kering Kabupaten Sumedang

Sama halnya dengan Gambar 7 grafik wilayah di Kabupaten Bandung. Wilayah Kabupaten Sumedang masih terbilang kurang dalam hal peng-irigasian sama halnya di Kabupaten Bandung, irigasi yang tidak merata mengakibatkan beberapa lahan kering dan sulit untuk dijadikan lahan bercocok tanam.

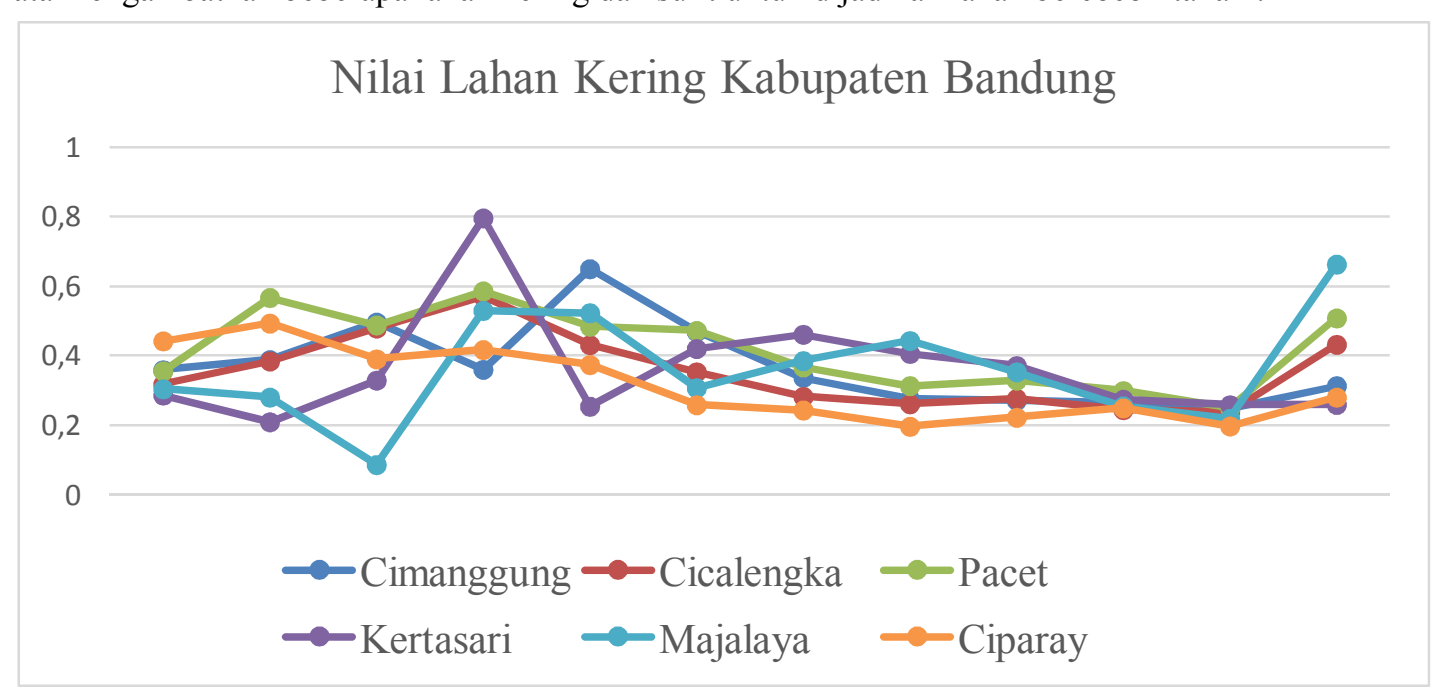

Gambar 7. Nilai Lahan Kering Kabupaten Bandung

\section{Tabel Estimasi Luas Lahan Sawah dan Lahan Kering}

Hasil analisis dalam penelitian ini menghasilkan luas total lahan sawah dan lahan kering, hasil estimasi memiliki nilai luas berbeda disetiap wilayahnya, seperti yang ditunjukkan Tabel 2. Hasil tabel menunjukkan luas lahan sawah tertinggi terdapat pada wilayah Rancaaekek seluas 2738,5338 hektar, Cicalengka seluas 998,30308 hektar, Cileunyi 964,81402 hektar, Tanjungsari 725,03885 hektar, Cimanggung 526,9368 hektar, Pacet 462,7426 hektar, Jatinangor 369 hektar, Sukasari 265,5072 hektar, Majalaya 232,25 hektar, Kertasari 177,45483 hektar, Ciparay 148,7261 hektar, Cibiru 31,61735 hektar, Rancasari 22,38744 hektar, dan luas sawah terkecil di kecamatan Pamulihan 22,19106 hektar.

Dari hasil survei yang dilakukan pada bulan September 2019 mendapatkan hasil penyebab wilayah yang masih sedikit menggunakan lahan untuk sawah dikarenakan kondisi lahan yang kering dan tidak terkena irigasi sehingga jika dijadikan lahan sawah resiko gagal tanam yang dialami para petani sangat besar. Jadi banyak petani yang memilih untuk bertanam tanaman yang tidak terlalu membutuhkan banyak air seperti bawang merah.

Lahan kering tertinggi terdapat pada wilayah Kertasari seluas 472,6892 hektar, Pacet 325,547097 hektar, Cimanggung 195,988291 hektar, Rancaekek 167,5961 hektar, Cicalengka 134,913783 hektar, Tanjungsari 131,477115 hektar, Cileunyi 110,562533 hektar, Sukasari 107,224055 hektar, Cibiru 88,3714 hektar, Rancasari 79,844063 hektar, Majalaya 58,5215537 hektar, Pamulihan 39,2762105 hektar, Ciparay 32,7956358 hektar, dan Jatinangor 28,593 hektar. Lahan kering yang terdapat diwilayah kabupaten Bandung 
dan Sumedang dikarenakan lahan yang tidak memiliki jumlah evaporasi potensial yang tidak melebihi jumlah curah hujan actual diwilayah tersebut untuk pertanian tanpa pengairan.

Lahan kering yang terdapat di wilayah kabupaten dan Sumedang dikarenakan lahan yang tidak memiliki jumlah evaporasi potensial yang tidak melebihi jumlah curah hujan actual diwilayah tersebut untuk pertanian tanpa pengairan.

Tabel 2. Luas Tutupan Lahan Sawah dan Lahan Kering

\begin{tabular}{|c|c|c|c|c|}
\hline \multirow{2}{*}{ Wilayah } & \multicolumn{2}{|c|}{ Jumlah Pixel } & \multicolumn{2}{|c|}{ Luas Lahan (Ha) } \\
\hline & Sawah & Lahan Kering & Sawah & Lahan Kering \\
\hline \multicolumn{5}{|c|}{ Kabupaten Sumedang } \\
\hline Tanjungsari & 3692 & 669,5 & 725,03885 & 131,477115 \\
\hline Sukasari & 1352 & 546 & 265,5072 & 107,224055 \\
\hline Pamulihan & 113 & 200 & 22,19106 & 39,2762105 \\
\hline Jatinangor & 1879 & 145,6 & 369 & 28,593 \\
\hline Cileunyi & 4912,97 & 563 & 964,81402 & 110,562533 \\
\hline Cibiru & 161 & 450 & 31,61735 & 88,3714 \\
\hline Rancasari & 114 & 630 & 22,38744 & 79,844063 \\
\hline Rancaekek & 13945 & 4570 & 2738,5338 & 167,5961 \\
\hline \multicolumn{5}{|c|}{ Kabupaten Bandung } \\
\hline Kertasari & 903,625 & 2407 & 177,45483 & 472,6892 \\
\hline Pacet & 2.326 & 1606 & 462,7426 & 325,547097 \\
\hline Cimanggung & 2261 & 998 & 526,9368 & 195,988291 \\
\hline Cicalengka & 5083,5 & 687 & 998,30308 & 134,913783 \\
\hline Majalaya & 1181,7 & 298 & 232,25 & 58,5215537 \\
\hline Ciparay & 650,98 & 167 & 148,7261 & 32,7956358 \\
\hline Total & 38576 & 13937 & 7686 & 1973 \\
\hline
\end{tabular}

Akurasi Klasifikasi Tutupan Lahan dan akurasi klasifikasi kappa statistik dihitung dan diperkirakan berdasarkan sampel dan matriks konfusi pada hasil klasifikasi data Citra Landsat 8 EVI menggunakan pengkelas variabel confusion matrix error pada scripts API Google Earth Engine (GEE) hasil akurasi ditunjukkan pada TabeL 3. Akurasi overall dari total klasifikasi lahan sawah dan lahan kering adalah 87,31\%.

Hasil kappa menunjukkan nilai yang lebih dari $85 \%$ dan dapat dikatakan hasil perhitunggan akurasi klasifikasi akurat dan dapat digunakan sebagai pertimbangan dalam penentuan penggunaan lahan dan pengolahan lahan di waktu yang akan datang. United States Geological Survey (USGS) telah menetapkan tingkat ketelitian klasifikasi atau interpretasi minimum dengan menggunakan penginderaan jauh yaitu kurang dari 85\% (USGS, 2016). Akurasi yang dianjurkan untuk digunakan adalah akurasi kappa karena menggunakan semua elemen dalam perhitungan matriks.

Berdasarkan nilai akurasi memberikan ketelitian yang cukup tinggi karena memenuhi syarat yang ditetapkan oleh USGS yang menyatakan ketelitian interpretasi lebih dari 85\% sehingga hasil klasifikasi citra Landsat 8 di Kabupaten Bandung dan Kabupaten Sumedang dapat digunakan untuk berbagai macam tujuan salah satunya untuk perluasan sawah dan penggunaan lahan kering untuk sawah. Pemanfaatan Peta Tutupan Lahan dapat digunakan untuk Investigasi Calon pengairan Irigasi dari hasil klasifikasi kelas tutupan lahan sawah dan kering Kabupaten Bandung dan Sumedang yang ditunjukkan pada Tabel 2.

Tabel 3. Perhitungan Akurasi Kappa Peta Tutupan Lahan

\begin{tabular}{lllllll}
\hline & $\begin{array}{l}\text { Badan } \\
\text { Air }\end{array}$ & Sawah & Bangunan & $\begin{array}{l}\text { Lahan } \\
\text { Kering }\end{array}$ & Hutan & $\begin{array}{l}\text { Total } \\
(\text { User })\end{array}$ \\
\hline Badan Air & 4 & 1 & 0 & 0 & 1 & 6 \\
Sawah & 0 & 228 & 14 & 2 & 23 & 267 \\
Bangunan & 0 & 26 & 105 & 4 & 11 & 146 \\
Lahan Kering & 0 & 1 & 0 & 59 & 6 & 66 \\
Hutan & 0 & 20 & 16 & 2 & 478 & 516 \\
Total (Producer) & 4 & 276 & 135 & 67 & 579 & 1001 \\
Overall Accuracy & $66,67 \%$ & $85,39 \%$ & $71,91 \%$ & $89,39 \%$ & $92,63 \%$ & $87,31 \%$ \\
Total Luas (Hektar) & 44284,8 & 7685,5 & 90944,62 & 1973,4 & 29347,15 & - \\
\hline
\end{tabular}




\section{SIMPULAN}

Hasil analisis bertujuan dapat memberikan solusi dalam penangan permasalahan lahan kering dapat diatasi dengan menggunakan sistem pengairan irigasi agar dapat dimanfaatkan sebagai lahan pertanian dan dapat membantu dalam mengatasi permasalahan penentuan waktu musim tanam lahan sawah dimusim kemarau. Waktu tanam yang sering digunakan untuk musim tanam sawah pada bulan Oktober, November, Maret, April, Mei, Juni dan September. Waktu tanam yang tidak sering digunakan untuk musim tanam pada bulan Juli, Januari dan Februari.

\section{REFERENSI}

Hairil Anwar, 2011. Perkembangan Tumbuhan (Phenophase). Biologi. Universitas Lampung

Huete, A., Didan, K., Leeuwen, W.V., Miura, T., Glenn, E. MODIS Vegetation Indices. Land Remote Sensing and Global Environmental Change. Springer. New York.

Jaya INS, 2015. Tehnik Mendeteksi Lahan Longsor Menggunakan Citra Spot Multiwaktu: Studi Kasus di Teradomari, Tochio, dan Shidata Mura, Niigata, Jepang. Di Jurnal Manajemen Hutan Tropika. 10(1):31-48.

Jaya INS. 2010. Analisis Citra Digital Perspektif Penginderaan Jauh untuk Pengelolaan Sumber Daya Alam. Fakultas Kehutanan. Institut Pertanian Bogor. Terdapat di Jurnal Teknotan 10(2): 66

Justice Associates. 2014. Lifecycles/Phenology. www.sws-wis.com/lifecycles

Lili Somantri, 2009. Teknologi Penginderaan Jauh (Remote Sensing). Dosen Pengampu Mata Kuliah Penginderaan Jauh dan Sistem Informasi Geografis Jurusan Pendidikan Geografi UPI. Bandung

Martinez, B. \& Gilabert, M. A. 2010. Vegetation Dynamics from NDVI Time Series Analysis Using The Wavelet Transform. Remote Sensing of Environment 113 (2009) 1823-1842

Sakamoto, T., Yokozawa, M., Toritani, H., Shibayama, M., Ishitsuka, N. \& Ohno, H. 2015. A Crop Phenology Detection Method Using Time-Series MODIS data. Remote Sensing of Environment, Vol. 96, pp. 366-374

Sari, D.K. 2010. Estimasi Produktivitas Air Tanaman Padi Sawah di Wilayah Tropis Berbasis Kalender Tanam Heterogen Menggunakan Teknologi Peninderaan Jauh. Jurusan Teknik Geodesi \& Geomatika - Institut Teknologi Bandung.

Sari, D.K., Ismullah, I.H., Suladi, W.N., dan Harto, A.B. 2010. Detecting Rice Phenology in Paddy Fields with Complex Cropping Pattern Using Time Series MODIS Data A Case study of Northern Part of West Java - Indonesia. ITB Journal of Science, 42 A, No. 2, pp. 91-106.

Son, Nguyen-Thanh., Chen, Chi-Farn., Chen, Cheng-Ru., Duc, Huynh-Ngoc., Chang,Ly-Yu. 2014. A Phenology-Based Classification of Time-Series MODIS Data for Rice Crop Monitoring in Mekong Delta, Vietnam. Remote Sensing. 6, 135-156; doi: 10.3390/rs6010135.

USGS. 2016. LANDSAT 8 (L8) DATA USERS HANDBOOK. Department of the Interior U.S. Geological Survey 